\title{
How Social Workers Portray Children's Perceptions When Constructing Their Identities
}

\author{
Elin Hultman ${ }^{1} \&$ Ann-Christin Cederborg ${ }^{2}$ \\ ${ }^{1}$ The Swedish Institute for disability research/ Department of Behavioural Sciences and Learning, Linköping \\ University, Linköping, Sweden \\ ${ }^{2}$ Department of Child and Youth Studies, Stockholm University, Stockholm, Sweden \\ Correspondence: Elin Hultman, The Swedish Institute for disability research/ Department of Behavioural Sciences \\ and Learning, Linköping University, S-581 83 Linköping, Sweden. Tel: 46-13-282-097. E-mail: \\ elin.hultman@liu.se
}

Received: April 20, 2013 Accepted: May 8, 2013 Available online: May 27, 2013

doi:10.11114/ijsss.v1i2.130

URL: http://dx.doi.org/10.11114/ijsss.v1i2.130

\begin{abstract}
Constructions of institutional identities are necessary when assessing children's needs and making intervention decisions. To be able to make holistic descriptions of children's identities, social workers have to listen to children's perceptions of themselves and their surroundings. In this study we explore how social workers construct children's identities when portraying the children's perceptions in social investigations conducted according to the BBIC model when concerns have been expressed about the children's health. Inspired by a discursive analytical approach, we focused on the language used.

We analysed descriptions of children's perceptions in 35 written investigations. We found that in terms of words used, the children's perceptions were given greater attention than those of parents and others (e.g. teachers, doctors). When focusing on the quality of these constructions, the main patterns found were that social workers more frequently submitted non-explanatory rather than explanatory descriptions.

We also found that social workers differ in the way they handle the task of reporting children's voices. These findings indicate that the use of the BBIC manual needs to be developed to ensure children are not just listened to and their perceptions described, but also that children are constructed as agents of their life. To obtain a holistic view of children's life-world, there is a need of identity descriptions that include details of how children understand their problems, what they experience as positive and what is acceptable support for them.
\end{abstract}

Keyword: Social service investigations, identity construction, children's perception, non-explanatory descriptions

\section{Introduction}

Constructions of institutional identities are a necessity when assessing children's needs and making intervention decisions (Holstein \& Miller, 1993; Hyden, 1991; Pithouse \& Atkinson, 1988). Children's opinions should also be accounted for in social work assessments and decision-making (Andersson, Aronsson, Hessle, Hollander \& Lundström, 2001; Holland, 2004). This means that social workers have to listen to children's notions of themselves and their surroundings to be able to fully construct the children's identities. In this study we explore how social workers portray children's perception in social investigations.

We know from previous research that children's life situation is explained through parental behavior in social investigations (Holland, 2001, 2004; Kähkönen, 1999; Thomas \& Holland, 2010). Parents have also been described as the sole cause of children's life situation (Dingwall, 1983; Hall et al., 2006; Hultman et al., forthcoming; Parton, Thorpe \& Wattam, 1997; Thorpe, 1994; Van Nijnatten \& Hofstede, 2003; Wattam, 1997; White, 2003). It has also been found that parents (Mattson, 2002) and professionals (Hennum, 2011; Hydén, 1995) are given priority in describing, defining and interpreting children's identities.In addition, children's opinions are sometimes completely omitted from written investigations (Andersson et al., 2001; Enell, 2009; Hollander 1985; Thomas \& Holland, 2010). 
In Sweden, the Convention on the Rights of the Child as well as the Swedish Social Services Act (SoL 201:453) make clear that children have the right to express their opinions in all matters that may affect their life situation (Convention on the Rights of the Child, art 12:1) and that children should be heard and allowed to give information that is important for social investigations (3:5 SoL 2001:453) provided that the child is not likely to be hurt when giving his or her point of view (11: 2 SoL 2001:453). The National Board of Health and Welfare (2006b) in Sweden has also decided that social services should use a revised version of the English documentation system, Integrated Children's System (ICS) (Parker Ward, Jackson, Aldgate \& Wedge, 1991), in Sweden called Focus on the need of the child (BBIC in Swedish) in their child protection work. The BBIC emanates from a holistic view of children's development. It is specifically influenced by Urie Bronfenbrenner's bioecological model (e.g. Bronfenbrenner, 1979; Bronfenbrenner \& Ceci, 1994). This view implies that a child's development is influenced by the quality of its close relations and societal environment. Individual and environmental prerequisites are seen as mutually shaping systems that continuously influence each other. This means that social workers are expected to focus on children's internal characteristics and their environmental conditions when investigating their life situation (Bronfenbrenner, 1979; Meadows, 2010). To achieve a holistic view of children's needs, the BBIC guidelines recommend seven areas that social workers should take into account: education; health; emotional- and behavioral development; identity; family and social relationships; social appearance; and children's ability to care for themselves. The BBIC investigative manual is divided in four sections where the child's, the parents' and other people's perceptions are noted along with the social worker's observations (National Board of Health and Welfare, 2006b). This means that the Swedish Social Services Act, the Convention on the Rights of the Child and BBIC guidelines are in line with theories that emphasize the importance of understanding children as active participants in their own life and that children have the right to express their experience (James, Jonks, \& Prout, 1998; Prout \& James, 1997; Qvortrup, 1994).

As the social workers have to assess complicated life situations, constructing these children's identities may be intricate. Furthermore, they may also have to consider varied, conflicting opinions about children's vulnerability and the causes of their problems as children under investigation can have an alternative perception of their identity to that of others (Andersson, 2001; Hollander, 2001). Therefore, social workers should listen to their perceptions (Cederborg, 2010) and they need to capture the child's opinion about potential vulnerability to be able to make assessments that make sense to the children (Helm, 2011). Knowledge of how social workers report children's perceptions is, however, limited.

\section{Aim of the Study}

The aim of this study is therefore to elucidate how social workers in Sweden construct children's identity specifically when they portrait the children's perception of themselves and their life situation. Our focus is on investigations conducted according to the BBIC model where concerns have been expressed about the children's health.

\section{Method}

\subsection{Data}

This study is part of a larger project exploring how social workers focus on children's physical and psychological health in written investigations of children carried out by the social services. The head of the social services in a medium-sized town in Sweden permitted access to written investigations, after which a list of all relevant investigations made by social workers during 2008 was delivered to us. We started with data from three of four districts. Next, all the data from the social service files were collected. We included all children aged $0-18$, a total of 272 investigations. Considering this sufficient for analysis, we refrained from using material from the fourth district. The children were investigated according to Chapter 11, § 11 and 2, of the Swedish Social Service Act (SoL 2001:453) in response to a report being submitted to the social services. Both parent- and child-related reports about the children's life situation were included. Applications from children and their families related to self-defined need of support were excluded.

At the time the data was collected, the implementation process of BBIC had not been completed, which means that all 272 cases included in the larger project were not conducted according to the model. For the purpose of this study we selected the investigations that were conducted according to the BBIC model, but also included the social workers' statements that at least one of the reasons for the investigation was a distinct concern about the child's health. Besides child ill-health, other specified concerns differed between the investigations. The concerns mentioned were (number of investigations in brackets) child neglect, (23), children's pre-/school problems (17), children's destructive lifestyle, (14), and conflicts between children and parents (4). In total, 35 investigations of 
16 girls and 19 boys fulfilled the inclusion criteria. The children were 5-17 years, (M=12.9 years) when the investigations were conducted.

\subsection{Theoretical Background}

We understand identity from a broadly social constructionist perspective, according to which a person's identity is seen as constituted in and through discourse and developed by and through social interaction. From such a perspective, the use of language is not a neutral activity. Rather, descriptions, representations and explanations express how things are perceived and should be understood. With this established we shall understand a person's identity as, in part, constructed through language. Language use is specific for a certain lived time and particular cultural horizon. As such, the way in which a person is understood and described can undergo contextual variation (Burr, 2003). Identity descriptions can also be seen as part of rhetorical devices used to accomplish social action (Benwell \& Stokoe, 2006). In the context of our study, social service investigations were analyzed as discursive practices constructing identity narratives through stories about children (Hydén, 1991; Holstein \& Miller, 1993). The social workers' descriptions of children's own perceptions and experiences were seen as part of those stories.

\subsection{Analytical Procedure}

As mentioned above, we were inspired by a discursive analytical approach that emanates from an understanding of discourses as action-oriented (Potter, 2003). A principal implication of this approach is that descriptions of persons need to be analyzed in their situated context (Potter \& Wetherell, 1995; Taylor, 2001; Wetherell \& Potter 1992). Inspired by Potter \& Wetherell (1987) we have focused on language use in the context of social workers' constructions of children's perceptions of themselves and their life situations. When conducting our analysis we searched for patterns of variation and consistency in both the contents and structure of the social workers' accounts.

Our data involve descriptions of children's perceptions from all seven dimensions of the BBIC model. To begin, the first author selected all sections in which social workers accounted for children's own experiences and opinions. Once the relevant passages were selected, the author carried out repeated readings of them, in order to find both similarities and differences in language use. The findings were then discussed between the two authors, both of whom, collaboratively, organized the data into themes that could help explain the questions posed by this study. During the fourth phase of the process, both authors reread the social workers' descriptions in relation to the arrangement of the chosen themes. During this collaborative process, some themes were rejected, and new themes emerged. Finally, when both authors agreed upon the veracity of the themes chosen the analytic process ended. The results presented below are the main findings of this analytical process.

\subsection{Ethical Considerations}

The project was approved by the Regional Ethical Committee in Linköping, Sweden (Dnr 221-08). Details and references to persons and places that might enable identification have been removed. In the excerpts, the child's name is referred to as X. Names of other persons or places are explained in brackets. Expressions that are irrelevant to the points being made have been removed from the excerpts. This is shown with ellipsis [...].

\section{Findings}

The children's perceptions were reported in 29 out of 35 investigations with variation in frequency.

Table 1. Frequencies of children's perception in different dimensions $(n=29)$

\begin{tabular}{lc}
\hline Dimension & Number of investigations \\
\hline Education & 29 \\
Family and social relationships & 29 \\
Health & 22 \\
Emotional and behavioral development & 22 \\
Identity & 17 \\
Children's ability to care for themselves & 9 \\
Social appearance & 4 \\
\hline
\end{tabular}


As seen in Table 1, there were differences in where children's perceptions were reported between the 7 dimensions included in the BBIC manual.

The social workers used $72-3544$ words with a mean of 885 words in the 29 investigations where children's perspectives were accounted for. In these 29 cases the social workers used 0-2018 words, with a mean of 700 words, when relating parent's opinions about the children. Social workers used 27-2430 words, with a mean of 746 words, when describing other people's perspectives on the children, such as those of teachers and health professionals. In terms of words used, the construction of children's perceptions was given the most prominent attention.

We found variations in the reporting of children's voices, however. The main pattern found with respect to the quality of the constructions was that social workers more frequently submitted non-explanatory rather than explanatory descriptions when constructing children's identities. This pattern was found regardless of which aspects of children's life were portrayed. We present our findings below in two themes with subthemes.

\subsection{Non-explanatory Descriptions}

\subsubsection{Lacking Information about Children's Opinions}

Sometimes the portrayal of children's opinions was brief and of limited extent. Social workers merely referred to the opinion the child expressed of the matter at hand. The following example is from an investigation of a 17-year-old boy about whom there is concerns related to his psychological health, lack of occupation, addiction to drugs and criminal behavior. This extract is about his experiences of his family.

\section{$X$ describes his family as very important}

\subsubsection{Simplified Explanation of Children's Opinions}

Even when children's feeling or behaviors are accounted for, sometimes they were rendered only briefly. There are also limited descriptions of how children realize that something they experience has consequences for their overall life. This was found in an investigation of an 11-year-old boy whose school had reported concerns about his absence due to stomach ache. When describing how he perceives his health to be, the rendition is simplified and not connected to a reason.

$X$ says that he quite often has stomach ache. It can last almost all day. It happens at school, at home and during his spare time.

This girl is 14 years old and there is concern about whether or not she has been abused. The girl's perception of her health is briefly mentioned and the cause of her feelings is not explained despite her saying that she continuously thinks about her experiences.

$X$ says that she is not feeling well after everything that has happened to her. She says that it is something she thinks about a lot.

The same was found when children's opinions diverged from the stated reason for conducting an investigation. In the case of a 12-year-old boy about whom there are concerns related to his problems at school and his problematic well-being, the description of the boy's perception is simplified and is unconnected to the actual worries.

$X$ thinks he is fine. He says that if he does something stupid, it feels bad and he thinks about it.

\subsubsection{Lacking Information about Children's Feelings}

Some accounts were constructed as statements about the children's life without information about their feelings. This example is from the 14-year-old girl described above who was suspected of being abused. Her perception of her friends is described below.

$X$ says that she has friends she meets in her spare time and they usually meet in (name of a place)

\subsubsection{Vague Rendition of Children's Perceived Future Needs}

Renditions of children's perceptions were mainly focused on their previous and present situation. Children's opinions about their future needs are rarely recounted, however. If children's wishes for the future were included, their perceptions were vague. One example of this is the 17-year-old boy mentioned above, about whom there are concerns related to his drug problems, psychological health and unsatisfactory situation at school. When his needs for behavioral development are described, the only thing mentioned is his wish to get away from his friends. 
$X$ says he needs to get away from some of his friends for a couple of months.

Another example is a 15-year-old boy whose school has expressed concerns about his psychological health and his problematic situation at school. When rendering how he thinks he could be helped, it is not made clear what type of interventions he desires.

$X$ is not concerned about his performance at school. He has been tired of school, unmotivated to do schoolwork and he has also played truant. X says he has behaved disruptively in class, bullied others and has being bullied himself. He wants help with his difficulties at school.

\subsubsection{Limited Description of What Children Appreciate}

With few exceptions the descriptions mainly involved renditions of problematic aspects of children's life. Even when aspects that children appreciate are described, there is no explanation of how they might work as a supportive aspect in the children's life. Below is an example from a case involving a 15-year-old boy where the school staff had expressed concerns about his difficulties with peer relations at school. The social worker referred to his pleasure at being with his friends and listening to music during his spare time in the following way.

$X$ says that he likes being with his friends and listening to music. He listens to rock music.

\subsection{Explanatory Descriptions}

\subsubsection{Coherent Rendering}

There were exceptions to non-explanatory descriptions, however. Some social workers also gave more coherent pictures of the children's perceptions than others did. An example of this was found in one investigation of a 16-year-old girl. The reasons for conducting an investigation were concerns for her situation at home at school, and for her health. When the social worker recounts the girl's perception of her situation at school, the description includes previous and current relations to school mates but also her opinions about school work and her attendance at school. The reasons for her behavior and the consequences of others' behavior toward her are also portrayed. Despite the coherent descriptions of how she perceives her problems, the girl's view about her needs for future support is not developed, however.

$X$ says she is in the grade 9. She says she is behind in most subjects since she has missed out a lot because she has played truant. It was at the end of grade 8 that everything started to go wrong, says X. She played truant more often and she was hanging out with friends that were drinking alcohol and using drugs. $X$ says that in the beginning it was some kind of protest against her family that had always seen her as gentle and quiet. $X$ also says that one girl was bullying her. According to $X$ the bullying led to her having low self-esteem, which makes her not want to attend sports at school.

$X$ says that she does not enjoy her new class at school. She perceives her class as noisy and says that everybody "screams a lot". However, she points out that she is satisfied with her teachers and says that she has good contact with her mentor. She says she finds it easy to learn new things in school. At the same time she finds it hard to concentrate and remember to do things like her homework... X says that she needs to manage school since she wants to get into high school.

A further example of a coherent rendition is another 16-year-old girl who has psychological health problems. The description of her health is detailed and involves her perception of improvement during the time of the investigation.

$X$ talks about her panic attacks, that they only come when she is at home. X starts shaking, her body goes tense and she finds it hard to breathe, feels dizzy and sometimes she faints. She usually goes out in the forest to calm down. The attacks come when she feels she wants to give up on life. She then goes out and wants to be on her own. She thinks it is best to keep her problems to herself so that she can forget about them when she spends time with others, otherwise she will just be reminded of them all the time... at the end of the investigation she says she is feeling much better now and that she has not had any panic attacks for a long time.

\subsubsection{Problem-oriented Focus}

Even when children's perspectives were illustrative, the main focus was on problematic aspects of their identity. When unproblematic aspects were described, these were generally simplified and briefer than descriptions of difficulties. This is illustrated below through the example of a 15-year-old-girl who had dysfunctional family and peer relations. 
In the interview, $X$ assesses her physical health as very good, which is the highest of the identified options: bad, quite well and very good. At the time of the interview, $X$ states that she feels downhearted or depressed and that she has been feeling psychologically unwell every day for the past month. She has also experienced severe anxiety and serious thoughts of suicide during that period. Previously, but not for the last 30 days, she has also experienced severe depression, severe anxiety, serious thoughts of suicide, and she tried to commit suicide by taking too many painkillers. She also says that she has had an eating disorder and harmed herself. $X$ tells the social worker that during the autumn she cut herself on the forearm with a knife when she was visiting her parents. She says she did it because she found it difficult to be at home with her mum and dad where no one cared about her and that she did not feel part of things.

\section{Discussion}

In this study we sought to uncover how social workers construct children's identities when portraying children's perceptions in social investigations. In contrast to previous findings (Andersson et al., 2001; Cederborg \& Karlsson, 2001; Hennum, 2011; Holland 200; Kähkönen, 1999; Thomas \& Holland, 2010), this study shows that children seem to be involved, and are represented, in the investigations conducted by social workers. However, even if investigations conducted according to the BBIC manual have certain sections in which children's views are supposed to be portrayed, we found variations in quality in the way social workers understand their assignments. Most of the cases studied involved non-explanatory descriptions of children's perceptions. These reports were simplified: they lacked information about what children appreciated in their lives as well as their opinions and feelings, alongside their expressed needs for the future. Descriptions of the unproblematic aspects of their lives were also fewer and briefer than the problematic aspects.

There were exceptions, however. Some social workers offered more explanatory accounts, giving more coherent versions of the children's perceptions. These social workers put more effort into visualizing children's voices by presenting richer, more detailed views, involving feelings and opinions from them. Nonetheless, even when narratives were more explanatory, the focus remained on problems rather than on what children appreciated. Moreover, insights into what children wanted for the future were often left underdeveloped.

This means that even if the construction of children's identities varied in quality, they remained focused on difficult relations with parents, problematic health and problems at school rather than on situations and relations that children appreciate. This finding is in line with previous studies, which show that social workers portray troublesome identities (Börjesson, 2008; Hennum, 2011; Hydén, 1991; Thomas \& Holland, 2010). This is not necessarily surprising considering the reasons for conducting the investigations. In the present study, social workers are investigating concerns about children's health and exposure to various other vulnerable life situations. However, the guidelines for the BBIC model state that social workers are expected to consider both problematic and supportive aspects (National Board of Health and Welfare, 2006a, b). Further, this study shows that some descriptions lacked information about children's views concerning their needs and how motivated they were for future intervention. Thus the subjective interest of the children is not taken into consideration (Petersson, 2003). This is problematic as such information can serve as a basis for understanding how motivated children are to receive support from social welfare.

Constructing identities without considering children's own understanding of how their problems influence their life, what they experience as positive and what is acceptable support is to underrate their capacity to give voice to their opinions. Our findings indicate that children in social service investigations are not always described as agents of their lives and therefore are not portrayed as actively taking part in the production and reproduction of their own life and well-being (Prout \& James, 1997). To make a holistic assessment possible, it is important to ensure that children's opinions about their needs and interventions are included in investigations (Andersson, 1998 a, b; Andersson et al, 2001; Backe- Hansen \& Havik, 1997; Butler \& Williamson, 1994; Hagbard \& Esping, 1992; Holland \& Thomas, 2010; Hultman, 2012) as their perception may be different from that of social workers or other informants (Alanen, 1994; Andersson et al., 2001; Gleason \& Evans, 2004; Hollander: 2001; Mason, 2008).

\section{Conclusion}

In Sweden, social service legislation and regulations emphasize that children should be treated as agents who actively take part in their own life. Our findings indicate that this may not be accomplished even if children's opinions about their life situation are included. Although there were variations, most of the investigations involved reports that were vague, with sparse descriptions of children's own opinions and which focused mainly on problems in the children's life. As a result, the construction of children's identities was limited. These findings indicate that the use of the BBIC manual needs to be developed to ensure that children are not just 
listened to and their perceptions described, but are also constructed as agents of their life. To acquire a holistic picture of children's life world, identity descriptions are required that include details of how children understand their problems, what they experience as positive and what type of support they find acceptable.

\section{Acknowledgements}

The authors are grateful for the cooperation of the management and staff of the social services, who provided the investigations which made this study possible.

\section{References}

Alanen, L. (1994). Gender and Generation: Feminism and the "Child Question". In J. Qvortrup, M. Bardy, G. Sgritta, \& H. Wintersberger (Eds.), Childhood Matters (pp. 27-42). Avebury, UK: Aldershot.

Andersson, G. (1998a). Barnintervju som forskningsmetod [Interviewing the child as a research methodology]. Nordisk Psykologi, 50(1), 18-41.

Andersson, G. (1998b). Föräldrakontakt och familjetillhörighet ur fosterbarns perspektiv [Parental contact and family belonging from the perspective of foster children ]. Socialvetenskaplig Tidskrift, 5(1), 3-23.

Andersson, G. (2001). Jag försöker gå framåt men vinden drar mig bakåt - en barndom utan kontinuitet [I try to go forward but the wind pulls me back - a childhood without continuity]. In K. Aronson (Ed.), Haverier $i$ social barnavård? Fem fallstudier [Breakdowns in child welfare? Five case studies] (pp. 36-77). Stockholm, Sweden: Förlagshuset Gothia.

Andersson, G., Aronson, K., Hessle, S., Hollander, A., \& Lundström, T. (2001). Inledning [Introduction]. In K. Aronson (Ed.), Haverier i social barnavård? Fem fallstudier [Breakdowns in child welfare? Five case studies] (pp. 9-21). Stockholm, Sweden: Förlagshuset Gothia.

Backe-Hansen, E., \& Havik, T. (1997). Barnevern på barns premisser [Child protection on the child's terms]. Gyldendal, Norway: Ad Notam.

Benwell, B., \& Stokoe, E. (2006). Identity and discourse. Edinburgh, UK: Edinburgh University Press.

Börjeson, M., \& Palmblad, E. (2008). Strultjejer, arbetssökande och samarbetsvilliga. Kategoriseringar och samhällsmoral $i$ socialt arbete [Troublesome girls, job seekers and cooperators: the role of categorization and social morality in social work]. Stockholm, Sweden: Liber.

Bronfenbrenner, U. (1979). The ecology of human development. Experiments by Nature and Design. Cambridge, US: Harvard University Press.

Bronfenbrenner, U., \& Ceci, S. J. (1994). Nature-Nurture Reconceptualized in Developmental Perspective: A Bioecological Model. Psychological Review, 101(4), 568-586. http://dx.doi.org/10.1037/0033-295X.101.4.568

Burr, V. (2003). Social constructionism (2nd ed.). East Sussex, UK: Routledge.

Butler, I., \& Williamson, H. (1994). Children speak: children, trauma and social work. Harlow, UK: Longman.

Cederborg, A-C. (2010). Att intervjua barn. Vägledningförsocialsekreterare.[Interviewing children. Guidelines for social workers].Stockholm, Sweden: Stiftelsen Allmänna barnhuset.

Cederborg, A-C., \& Karlsson, Y. (2001). Omhändertagande med barnets perspektiv. [Being taken intocare from the child'sperspective]. Socialvetenskaplig tidskrift, 3, 163-179.

Dingwall, R., Eekelaar, J., \& Murray, T. (1983). The Protection of Children: State intervention and family life, Oxford, UK: Blackwell.

Enell, S. (2009). Barnet $i$ utredningen: en uppföljningsstudie om barns ställning i barnavårdsutredningar genomförda $i$ BBIC [The child in the investigation: a follow-up study of the position of children in child protection investigations conducted according to the BBIC]. Jönköping, Sweden: Luppen kunskapscentrum.

Gleason, T. R., \& Evans, M. E. (2004). Perceived vulnerability: a comparison of parents and children. Journal of Child Health Care, 8(4), 279-287. http://dx.doi.org/10.1177/1367493504047318

Hagbard, S., \& Esping, U. (1992). Med barns ögon. Om ett barnrelaterat förhållningssätt i familjehemsvården [Through the eyes of the child. A child- related approach to foster care]. Stockholm, Sweden: Allmänna Barnhuset.

Hall, C., Slembrouck, S., \& Sarangi, S. (2006). Language Practices in Social work. Categorisation and accountability in child welfare. London, UK: Routledge. 
Helm, D. (2011). Judgments or assumptions? The role of analysis in assessing children and young people's needs. British Journal of Social Work, 41, 894-911. http://dx.doi.org/10.1093/bjsw/bcr096

Hennum, N. (2011). Controlling children's lives: covert messages in child protection service reports. Child and Family Social Work, 16(3), 336-344. http://dx.doi.org/10.1111/j.1365-2206.2010.00744.x

Holland, S. (2001). Representing Children in Child Protection Assessments. Childhood, 8(3), 322-339. http://dx.doi.org/10.1177/0907568201008003002

Holland, S. (2004). Child and family assessment in Social work practice. London, UK: Sage.

Hollander, A. (1985). Omhändertagande av barn: en studie av barnavårdsmål vid förvaltningsdomstolarna åren 1974, 1977 och 1982 [Taking Children Into Care. A Study of Child Care Cases in Administrative Courts in 1974, 1977 and 1982]. Stockholm, Sweden: Aktuell juridik.

Hollander, A. (2001). En mammas motstånd - om samtycke vid ett omhändertagande [A mother's resistance on consenting to compulsory care]. In K. Aronson (Ed.), Haverier i social barnavård? Fem fallstudier [Breakdowns in child welfare? Five case studies] (pp. 102-138). Stockholm. Sweden: Förlagshuset Gothia.

Holstein, J., \& Miller, G. (1993). Social Constructionism and Social Problems Work. In J. Holstein, \& G. Miller (Eds.), Reconsidering Social Constructionism (pp.151-172). New York, US: Aldine de Gruyer.

Hultman, E. (2012). Gestaltning av barns röster i socialtjänstens skriftliga utredningsbedömningar. [Portraits of children's voices in social services written investigation assessments]. Tidsskriften Locus, 1-2, 69-80.

Hultman, E., Cederborg, A-C., \& Fälth Magnusson, K. (forthcoming). The challenge of assessing children's ill-health and needs in social services investigations.

Hydén, L. C. (1991). Barnavårdsutredningen som identitet [The child welfare investigation as identity]. Rapport 1991:6. Stockholm, Sweden: Forsknings- och utvecklingsbyrån Stockholms socialförvaltning.

Hydén, L. C. (1995). Det sociala misslyckandet som berättelse- att återställa den moraliska ordningen [Social failure as narrative- restoring the moral order]. Socialvetenskaplig Tidsskrift, 3, 194-207.

James, A., Jonks, C., \& Prout, A. (1998). Theorizing Childhood. Cambridge, UK: Polity Press.

Kähkönen, P. (1999). The assessment of parenting in child welfare practice. Children and Youth Services Review, 21(7), 581-603. http://dx.doi.org/10.1016/S0190-7409(99)00040-7

Mason, J. (2008). A Children's Standpoint: Needs in Out-of-Home Care. Children and Society, 22, 358-369. http://dx.doi.org/10.1111/j.1099-0860.2007.00115.x

Mattson, T. (2002). Barnet och rättsprocessen. Rättssäkerhet, integritetssydd och autonomi i samband med beslut om tvångsvård [The Child in Statutory Care Proceedings - Legal Security, Protection of Personal Integrity and Autonomy in Connection with Decisions on Statutory Care]. Lund, Sweden: Juristförlaget. Dissertation.

Meadows, S. (2010). The Child as Social person. London, UK: Routledge.

Monds-Watson, A., Manktelow, R., \& McColgan, M. (2010). Social Work with Children when Parents have Mental Health Difficulties: Acknowledging Vulnerability and Maintaining the "Rights of the Child"'. Child Care in Practice, 16(1), 35-55. http://dx.doi.org/10.1080/13575270903369319

National Board of Health and Welfare (Socialstyrelsen). (2006a). Barn och unga i socialtjänsten. Utreda, planera och följa upp beslutade insatser [Children and youth in the social services. Investigate, plan and follow-up decided interventions]. Stockholm, Sweden: Socialstyrelsen.

National Board of Health and Welfare (Socialstyrelsen). (2006b). Grundbok: Barns behov i centrum [A daybook: Children's need in focus]. Stockholm, Sweden: Socialstyrelsen.

Parker, R., Ward, H., Jackson, S., Aldgate, J., \& Wedge, P. (1991). Looking After Children: Assessing Outcomes in Child Care. The report of an independent working party established by the Department of Health. London, UK: HMSO.

Parton, N., Thorpe, D., \& Wattam, C. (1997). Child protection: Risk and the moral order. Basingstoke, UK:Palgrave Macmillan.

Petersson, G. (2003). Med hänsyn till barnets vilja. Socialtjänstlagens barnperspektiv och den nya välfärdsstatens villkor [Considering the will of the child. The child perspective in the Social Services Act and the terms of the new welfare state]. In B. Sandin, \& G. Halldén (Eds.), Barnets bästa- en antologi om barndomens 
innebörder och välfärdens organisering [The best interest of the child - an anthology of the meanings of childhood and the organization of welfare]. Stockholm, Sweden: Brutus Östlings bokförlag Symposion.

Pithouse, A., \& Atkinson, P. (1988). Telling the case: occupational narrative in a social work office. In N. Coupland (Ed.), Styles of Discourse (pp.183-200). London, UK: Crome Helm.

Potter, J. (2003). Discourse analysis and discursive psychology. In P.M. Camic, J.E. Rhodes, \& L. Yardley (Eds.), Qualitative research in psychology: Expanding perspectives in Methodology and design (pp. 73-94). Washington DC, US: American Psychological Association.

Potter, J., \& Wetherell, M. (1987). Discourse and social psychology. Beyond attitudes and behavior. London, UK: Sage.

Potter, J., \& Wetherell, M. (1995). Discourse Analysis. In A.J. Smith, R. Harré, \& L. Van Langenhove (Eds.), Rethinking methods in psychology (pp.80-92). London, UK: Sage.

Prout, A., \& James, A. (1997). A New Paradigm for the Sociology of Childhood? Provenance, Promise and Problems. In A. James, \& A. Prout (Eds.), Constructing and Reconstructing Childhood: Contemporary Issues in the Sociological Study of Childhood (pp. 7-33). London, UK: Falmer Press.

Qvortrup, J. (1994). Childhood Matters: an introduction. In J. Qvortrup, M. Bardy, G. Sgritta, \& H. Wintersberger (Eds.), Childhood matters- Social theory, Practice and Politics (pp. 1-25). Aldershot, UK: Avebury.

Taylor, S. (2001). Locating and conducting discourse analytic research. In M. Wetherell, S. Taylor, \& S. J. Yates (Eds.), Discourse as data- a guide for analysis (pp.5-48) London, UK: Sage.

Thomas, J., \& Holland, S. (2010). Representing Children's Identities in Core Assessments. British Journal of Social Work, 40(8), 2617-2633. http://dx.doi.org/10.1093/bjsw/bcp154

Thorpe, D. H. (1994). Evaluating child protection. Maidenhead, UK: McGraw-Hill.

Van Nijnatten, C., \& Hofstede, G. (2003). Parental identity under construction. Discourse and conversation analysis of a family supervision order. In C. Hall, K. Juhila, T. Pösö, \& N. Parton (Eds.), Constructing Clienthood in Social Work and Human Services: Interaction, Identities and Practices (pp. 96-111). London, UK: Jessica Kingsley.

Wattam, C. (1997). Evaluating the evidence. In D. Platt, \& D. Shemmings (Eds.), Making Enquiries into Alleged Child Abuse and Neglect. Partnership with Families (pp. 232-247). Brighton, UK: Pennant professionals.

Wetherell, M., \& Potter, J. (1992). Mapping the language of racism. New York, US: Colombia University Press.

White, S. (2003). The Social Worker as Moral Judge. Blame, Responsibility and Case formulation. In C. Hall, K. Juhila, T. Pösö, \& N. Parton (Eds.), Constructing clienthood in Social Work and Human Services: Interaction, Identities and Practices (pp. 177-192). London, UK: Jessica Kingsley.

\section{(cc) EY}

This work is licensed under a Creative Commons Attribution 3.0 License. 